\title{
Selective expression of TLQP-21 and other VGF peptides in gastric neuroendocrine cells and modulation by feeding
}

\author{
Carla Brancia ${ }^{1}$, Cristina Cocco ${ }^{1}$, Filomena $D^{\prime}$ Amato $^{1}$, Barbara Noli ${ }^{1}$, Fabrizio Sanna ${ }^{2}$, Roberta Possenti ${ }^{3}$, \\ Antonio Argiolas ${ }^{2}$ and Gian-Luca Ferri ${ }^{1}$
}

${ }^{1}$ NEF-Laboratory, Department of Cytomorphology and ${ }^{2}$ Department of Neuroscience, University of Cagliari, 09042 Monserrato (Cagliari), Italy

${ }^{3}$ Institute of Neurobiology and Molecular Medicine, CNR, and Department of Neuroscience, Tor Vergata University, 00133 Rome, Italy

(Correspondence should be addressed to G-L Ferri; Email: ferri@unica.it)

\begin{abstract}
Although vgf gene knockout mice are hypermetabolic, administration of the VGF peptide TLQP-21 itself increased energy consumption. Agonist-antagonist roles are thus suggested for different VGF peptides, and the definition of their tissue heterogeneity is mandatory. We studied the rat stomach using antisera to $\mathrm{C}$ - or $\mathrm{N}$-terminal sequences of known or predicted VGF peptides in immunohistochemistry and ELISA. TLQP (rat $\mathrm{VGF}_{556-565}$ ) peptide/s were most abundant $(162 \pm 11 \mathrm{pmol} / \mathrm{g}$, mean \pm S.E.M. $)$ and were brightly immunostained in enterochromaffin-like (ECL) cells and somatostatin cells. A peptide co-eluting with TLQP-21 was revealed in HPLC of gastric and hypothalamic extracts, while the extended TLQP-62 form was restricted to the hypothalamus. Novel PGH (rat $\mathrm{VGF}_{422-430}$ ) peptide/s were revealed in ghrelin cells, mostly corresponding to low $\mathrm{MW}$ forms $(0 \cdot 8-1 \cdot 5 \mathrm{kDa})$, while VGF C-terminus peptides were
\end{abstract}

confined to neurons. VGF mRNA was present in the above gastric endocrine cell types, and was prominent in chief cells, in parallel with low-intensity staining for further cleaved products from the C-terminal region of VGF (HVLL peptides: $\left.\mathrm{VGF}_{605-614}\right)$. In swine stomach, a comparable profile of VGF peptides was revealed by immunohistochemistry. When fed and fasted rats were studied, a clear-cut, selective decrease on fasting was observed for TLQP peptides only $(162 \pm 11$ vs $74 \pm 5 \cdot 3 \mathrm{pmol} / \mathrm{g}$, fed versus fasted rats, mean \pm s.E.M., $P<0 \cdot 00001)$. In conclusion, specific VGF peptides appear to be widely represented in different gastric endocrine and other mucosal cell populations. The selective modulation of TLQP peptides suggests their involvement in peripheral neuro-endocrine mechanisms related to feeding responses and/or ECL cell regulation.

Journal of Endocrinology (2010) 207, 329-341

\section{Introduction}

The $v g f$ gene (non-acronymic) and its peptide products are proposed neuroendocrine regulators affecting food intake and/or energy balance (Salton et al. 2000, Levi et al. 2004), as well as other functions including water balance (Yamaguchi et al. 2007).

The $v g f$ gene and its derived peptides are expressed in many tissues, including the central and peripheral nervous system, the endocrine system and the gut, suggesting that multiple sites of VGF peptide production, as well as actions are likely (Salton et al. 2000). Deletion of the mouse vgf gene (knockout) resulted in thin, small, hyperactive and hypermetabolic animals (Hahm et al. 1999), with derangement of hypothalamic outflow pathways regulating peripheral metabolic tissues and energy homoeostasis (Hahm et al. 2002). More recently, an increased sympathetic drive in $V g f-/-$ mice appeared to induce increased lipolysis, decreased lipogenesis and brown adipocyte differentiation in white adipose tissue (Watson et al. 2009). Surprisingly, i.c.v. injection of the naturally occurring VGF-derived TLQP-21 peptide increased energy expenditure and body temperature, and prevented diet-induced obesity in mice (Bartolomucci et al. 2006), while reducing food intake in Siberian hamsters (Jethwa et al. 2007). It was proposed that further end products of the VGF precursor (yet to be characterised) could be responsible for inhibiting energy expenditure, thus explaining the relevant aspects of the knockout phenotype (Bartolomucci et al. 2007, Jethwa \& Ebling 2008).

Briefly, the $v g f$ gene encodes a VGF polypeptide of 617 or 615 amino acids (in rat/mouse and human respectively, Salton et al. 2000), with more than 12 fully conserved stretches of basic amino acid residues representing potential or demonstrated processing sites for neuroendocrine prohormone convertases, such as PC1/3 and PC2 (Trani et al. 2002). In cells and tissues, proteolytic processing yields diverse peptides, including some of low MW, which were preferentially released by various stimuli (Possenti et al. 1989, 1999, Trani et al. 1995). These include peptides encompassing the VGF C-terminal portion, TLQP-21 and TLQP-62 peptides, and the recently identified peptides NERP-1 and -2 (Trani et al. 2002, Bartolomucci et al. 2007, Yamaguchi et al. 2007, 
Bozdagi et al. 2008). While vgf gene expression is distinctly modulated in multiple models and conditions (Levi et al. 2004), differential processing and modulation of VGF peptides have been shown so far in the pituitary (Brancia et al. 2005), adrenal glands (D'Amato et al. 2008) and pancreas (Cocco et al. 2007).

The stomach is a complex organ involved in the regulation of food intake and in the response to feeding, and contains heterogeneous populations of endocrine cells including gastrin (G), enterochromaffin (EC), enterochromaffin-like (ECL) and somatostatin (D) cells (Solcia et al. 2000). The circulating hormone leptin is present and modulated not only in adipocytes, but also in gastric principal cells (Bado et al. 1998). The hormone ghrelin, acting on both food intake and $\mathrm{GH}$ secretion, is mainly released from gastric endocrine cells identified as P/D1 type in human and X/A-like type in rat (Rindi et al. 2002). A further novel hormone, apelin, is expressed in multiple gastric mucosal cells, including parietal cells, where from it participates in the regulation of acid secretion via ECL cells (Lambrecht et al. 2006). Most recently, the hypothalamic nesfatin-1 peptide was revealed in gastric ghrelin- and somatostatin-containing cells, with changes in connection with the nutritional status (Stengel et al. 2009).

We address the localisation and heterogeneity of several, including some novel, VGF peptides using antisera to short sequences corresponding to $\mathrm{N}$ - and $\mathrm{C}$-terminal regions of known or predicted cleaved peptides. VGF peptide modulation was studied in response to the major physiological stimulus of feeding versus fasting.

\section{Materials and Methods}

\section{Animals and tissue samples}

Sprague-Dawley rats (250-350 g, Harlan, Milan, Italy) were kept at $20{ }^{\circ} \mathrm{C}$ with free access to water throughout. In a first set of experiments, rats $(n=8$, of either sex, fed ad libitum) were kept under standard light-darkness cycle (dark: 1900-0700 h), deeply anaesthetised with diethyl ether vapour and were exsanguinated. The stomach was opened, pinned on cork and was immersion fixed in paraformaldehyde $(40 \mathrm{~g} / 1$, in $0 \cdot 1 \mathrm{~mol} / 1 \mathrm{PO}_{4}$ buffer for $3 \mathrm{~h}$ at $0-4{ }^{\circ} \mathrm{C}$ ). Further rats (three per cage) were kept under reversed light-darkness cycle (dark: 0900-2100 h, >4 weeks before killing), and received standard rat chow $(20 \mathrm{~g} / \mathrm{rat}$ ) once per day (at $0900 \mathrm{~h}$ ) for 2 weeks. These were allocated to either A) fasted group $(n=18)$, deprived of chow 2 days before the killing, or B) fed group $(n=18)$, fed as above until the killing. Rats were moved to the killing room one cage at a time (between 1200 and $1300 \mathrm{~h}$ ), deeply anaesthetised with diethyl ether vapour, hence, either exsanguinated (for tissue extraction: male, $n=12$ per group) or perfused transcardially with paraformaldehyde, while the same fixative $(\sim 3-5 \mathrm{ml})$ was rapidly injected into the stomach (for immunohistochemistry: $n=4$ males +2 females per group). From the latter animals, the brains were removed, the stomach was opened and emptied of contents and then both were washed and stored in PBSsucrose $\left(0 \cdot 01 \mathrm{~mol} / 1 \mathrm{PO}_{4}, \mathrm{pH} 7 \cdot 2-7 \cdot 4\right.$, containing $0 \cdot 15 \mathrm{~mol} / 1$ $\mathrm{NaCl}, 70 \mathrm{~g} / 1$ sucrose and $0 \cdot 2 \mathrm{~g} / 1 \mathrm{NaN}_{3}$ ). For the rat stomach, the glandular portion was sampled, including the oxyntic and antro-pyloric regions. Additional samples were taken from pigs (females and castrated males, 7-9 months, $n=10$, from a local abattoir). According to routine butchery procedures, pigs received a limited amount of food on the day preceding slaughtery. Samples of oxyntic, cardiac and pyloric mucosa $(\sim 4 \times 4 \mathrm{~cm})$ were deprived of muscolaris, stretched onto filter paper (mucosal side up), immersion fixed in paraformaldehyde $\left(40 \mathrm{~g} / 1\right.$, in $0 \cdot 1 \mathrm{~mol} / 1 \mathrm{PO}_{4}$ buffer for $3 \mathrm{~h}$ at $\left.0{ }^{\circ} \mathrm{C}\right)$ and stored in PBS-sucrose. For cryosectioning, tissue samples were oriented in aluminium foil moulds in cryoembedding medium (Cocco et al. 2003) and were frozen in the melting freon (cooled with liquid nitrogen). Sections $(5-6 \mu \mathrm{m})$ were cut using a cold-blade cryomicrotome (Microm HM-560, Walldorf, Germany) and were collected on slides coated with either poly-L-lysine (for immunocytochemistry) or 3-aminopropyltriethoxysilane (TESPA, Sigma, for in situ hybridisation, $20 \mathrm{ml} / 1$ in acetone, followed by overnight heating at $180^{\circ} \mathrm{C}$ ), air dried, wrapped in aluminium foil and stored in a liquid nitrogen tank (vapour phase) until used. For peptide extraction, the whole stomach from each rat was emptied of contents, rinsed in cold saline, blotted dry, weighed and coarsely minced with a scalpel. A portion of the brain encompassing the hypothalamus was taken in parallel. The above tissues were immediately homogenised in PBS ( $\sim 10 \mathrm{ml} / \mathrm{g}$ tissue, $3-5 \mathrm{~min}$, on ice) containing protease inhibitor cocktail (P8340, Sigma, $5 \mu \mathrm{l} / \mathrm{ml}$ ) using an UltraTurrax homogeniser (Ika-Werke, Staufen, Germany), heated in a vigorously boiling water bath (10-15 min) and centrifuged $(3000 \mathrm{~g}, 10-15 \mathrm{~min})$. Supernatants were kept frozen until used $\left(-20{ }^{\circ} \mathrm{C}\right.$ or lower $)$.

Experimental design and procedures were approved by the relevant ethical committee at the University of Cagliari and the national controlling body (Italian Ministry of Health) and were performed in accordance with the care and use of animals approved by the American Physiological Society and EEC Council Directive of 24 November 1986 (86/609) throughout.

\section{VGF peptide antibodies}

Antisera (Table 1) were raised against peptide sequences at the C-terminus of the VGF precursor protein or adjacent to the putative or demonstrated cleavage sites (Fig. 1) and were conjugated with either bovine thyroglobulin or keyhole limpet haemocyanin (KLH). At the C-terminal end of rat and mouse VGF, a $\mathrm{His}_{615}-\mathrm{Arg}_{616}-\mathrm{Pro}_{617}$ sequence is found, as opposed to $\operatorname{Arg}_{613}-\operatorname{Arg}_{614}-\operatorname{Pro}_{615}$ in human (Salton et al. 2000), hence antisera were raised against the corresponding nonapeptides conjugated at their N-terminus (Ferri et al. 1995). A peptide corresponding to human $\mathrm{VGF}_{603-612}$ (identical to rat $\mathrm{VGF}_{605-614}$ ), and immediately preceding 
Table 1 VGF peptide antisera

\begin{tabular}{|c|c|c|c|c|}
\hline Antigen & Short name & Use & Species & References \\
\hline Rat VGF $609-617$ & Rat VGF C-term.* & $\mathrm{I}, \mathrm{E}$ & Rabbit & Ferri et al. (1995) and Trani et al. $(1995,2002)$ \\
\hline Human VGF $607-615$ & Hum VGF C-term.* & 1 & Rabbit & Brancia et al. (2005) and Cocco et al. (2007) \\
\hline Rat $V_{G F_{605-614}}{ }^{* *}$ & HVLL & $\mathrm{I}, \mathrm{E}$ & Rabbit & D'Amato et al. (2008) \\
\hline Rat VGF $_{556-565}$ & TLQP & $\mathrm{I}, \mathrm{E}$ & G-pig & Brancia et al. (2005) \\
\hline Rat $V_{G F} F_{422-430}$ & Rat PGH & $\mathrm{I}, \mathrm{E}$ & Rabbit & Rindi et al. (2007) and D'Amato et al. (2008) \\
\hline Rat $V_{G F} F_{443-588}$ & b-gal-VGF $443-588$ & 1 & Rabbit & Ferri et al. (1992) \\
\hline
\end{tabular}

${ }^{*}$ C-terminus; ${ }^{* *}$ identical to human $\mathrm{VGF}_{603-612}$. b-gal, $\beta$-galactosidase; use: I, immunohistochemistry; E, ELISA; G-pig, guinea-pig.

the $\operatorname{Arg}_{613}-\operatorname{Arg}_{614}$ stretch found in human VGF, was conjugated at its N-terminus (HVLL peptide, corresponding to the C-terminus of the VGF precursor deprived of its last three amino acids). TLQP peptides were isolated from the rat brain and were proved to be cleaved from VGF at the rat $\mathrm{VGF}_{553-555}$ (Arg ${ }_{553}-\mathrm{PrO}_{554}-\mathrm{Arg}_{555}$ ) processing site (Trani et al. 2002), at least their N-terminal five amino acids (Thr-LeuGln-Pro-Pro) being identical in human and rat VGF. Hence, the rat $\mathrm{VGF}_{556-565}$ peptide was synthesised and conjugated at its C-terminus (Brancia et al. 2005). The rat $\mathrm{VGF}_{422-430}$ 'PGH' peptide, immediately preceding a putative Arg-ArgLys cleavage site, was conjugated via an N-terminal tyrosine (Ferri et al. 1995, D'Amato et al. 2008). The $\mathrm{VGF}_{443-588}$ fusion protein antiserum has been described previously in detail (Ferri et al. 1992).

\section{Immunohistochemistry and in situ hybridisation}

Sections were soaked in Triton X-100 (1 g/l in PBS for $1 \mathrm{~h}$; Merck), incubated with one, two or three primary antiserum/a (raised in different species, overnight at room temperature), hence with the relevant species-specific secondary antibody/ies (from donkey, conjugated with either AMCA, Cy2 or $\mathrm{Cy} 3$; Jackson Immunoresearch Laboratories, West Grove, PA, USA). Endocrine cell populations were characterised as follows: i) ECL cells by combined immunostaining for vesicular monoamine transporter 2 (VMAT-2; Chemicon, Temecula, CA, USA) and ghrelin, such cell type expressing VMAT-2 but not ghrelin (Rindi et al. 2002); ii) principal cells by immunostaining for pepsinogen II (Abcam, Cambridge, UK); iii) ghrelin, gastrin, somatostatin and serotonin-containing (EC) cells by

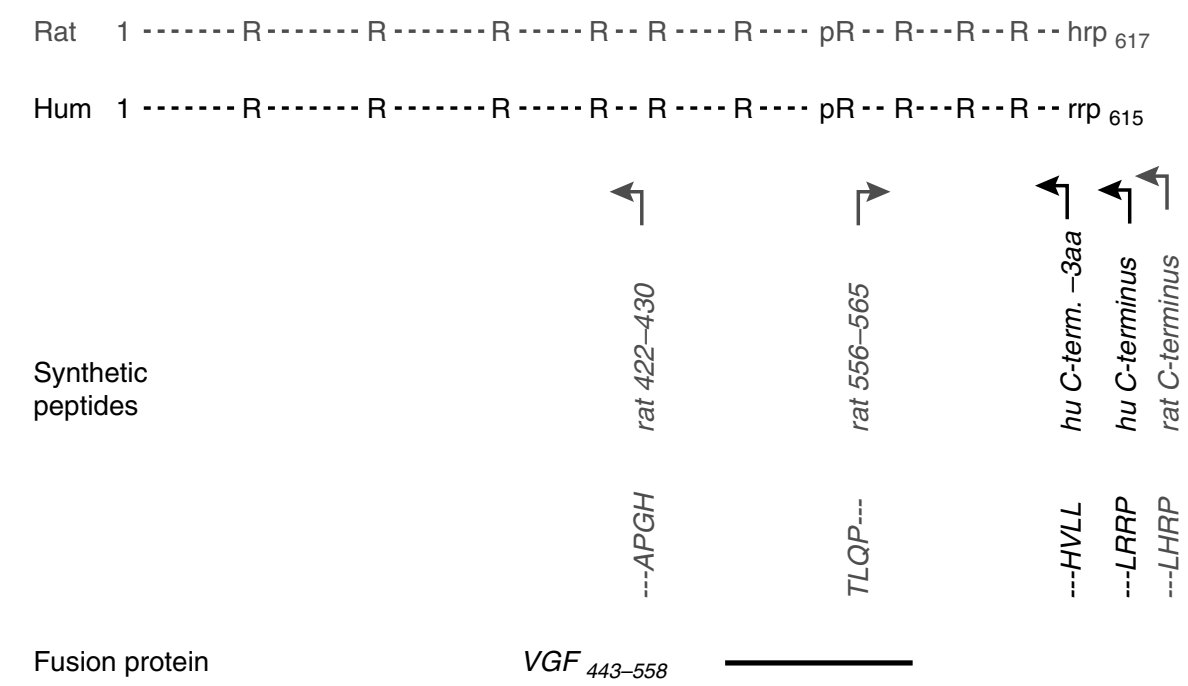

Figure 1 Scheme of the VGF precursor protein (rat and human), and peptides/fusion protein used to raise the antisera. Immunisations were aimed to obtain antibodies specific for sequences at the VGF C-terminus, or immediately adjacent to the demonstrated/putative cleavage sites ( $\mathrm{N}$-terminus of the TLQP peptide/s, C-terminus of HVLL and PGH peptides), hence, a cysteine residue was added at their other extreme and used for conjugation. Arrows indicate expected reactivity of antibodies, which would be selective for a free/cleaved N-terminus (for TLQP peptides), or C-terminus (HVLL, PGH and C-terminus peptides), whichever length or modification native peptides may show at their other extreme. The far longer fusion protein was intended to raise antibodies to multiple portions of its included VGF sequence, expectedly cross-reacting with the VGF precursor. 'rat'/'hum': schemes of rat and human VGF (precursor) protein respectively; ' $R$ ': putative/demonstrated cleavage sites, with two or more Arg/Lys basic residues; ' $\mathrm{pR}^{\prime}$ ': rat $\mathrm{Arg}_{553}-\mathrm{PrO}_{554}-\mathrm{Arg}_{555}$ processing site giving raise to TLQP peptides (Trani et al. 2002); 'rrp'/'hrp': last three C-terminal amino acids of rat/human VGF (Arg-Arg-Pro and His-Arg-Pro respectively). 
immunostaining for their respective hormone (anti-ghrelin, raised in sheep against a human octanoylated ghrelin 1-10 peptide conjugated to KLH; anti-gastrin, anti-somatostatin and anti-serotonin; Biomol, Exeter, UK). Washings were carried out in PBS, and antibodies were diluted in PBS containing $30 \mathrm{ml} / 1$ normal serum of the secondary donor species (donkey), and $30 \mathrm{ml} / 1$ normal serum (from a pool) of the same species being immunostained (either rat or pig). Routine controls included substitution of each layer, in turn, with PBS or pre-immune serum. In absorption controls, each primary antiserum was pre-incubated overnight with its own antigen in a range of concentrations $\left(0 \cdot 03-100 \mu \mathrm{mol} / 1\right.$, at $\left.0-4{ }^{\circ} \mathrm{C}\right)$. Absorption with $\sim 10 \mu \mathrm{mol} / 1$ concentrations of antigen, or higher, resulted in virtually complete prevention of the corresponding labelling in each case.

As described below (see section Results), distinct localisation patterns were shown with $\mathrm{VGF}_{443-588}$, TLQP and $\mathrm{PGH}$ peptide antibodies, hence, these were used for quantitation of the relevant co-localisation profiles versus hormones and/or other markers. Single- and double-labelled cells showing a visible (unlabelled) nuclear profile were counted in four rats per group (fed versus fasted), using three non-adjacent sections, two areas each (encompassing the whole mucosa, from muscularis mucosa to lumen).

For in situ hybridisation, $\sim 600 \mathrm{bp}$ fragment of rat VGF cDNA (BamHI-XhoI 235-854 bp from the ATG of the coding sequence) was cloned in both orientations, downstream of the T7 polymerase promoter in pGEM-4Z plasmid (Promega Corporation). Labelled antisense and sense probes were obtained by in vitro transcription of the linearised plasmids with T7 polymerase, using Megascript labelling kits (Ambion, Austin, TX, USA) and digoxigenin-11-UTP (Roche, Monza, Italy). Sections were digested with proteinase $\mathrm{K}(1 \mu \mathrm{g} / \mathrm{ml}$ in PBS containing $1 \mathrm{mmol} / 1$ EDTA for $3 \mathrm{~min}$; ICN, Milan, Italy), treated with glycine (25 mmol/l in PBS for $5 \mathrm{~min}$ ) and post fixed in paraformaldehyde (40 g/l in PBS for $5 \mathrm{~min}$ ). After a pre-incubation step with the hybridisation buffer (at $70{ }^{\circ} \mathrm{C}$ for $1 \mathrm{~h}$ ), preparations were hybridised overnight with the relevant probe (at $70^{\circ} \mathrm{C}$, as described in Moorman et al. 2001). After RNAse digestion and stringency washes (at $70^{\circ} \mathrm{C}$ ), sections were incubated with alkaline phosphatase-labelled anti-digoxigenin Fab fragment antibodies (Roche), using a 4-nitroblue tetrazolium chloride-5-bromo-4-chloro-3-indolyl-phosphate substrate kit (Vector, Burlingame, CA, USA). Controls included the use of the corresponding sense probe, substitution of the probe with the hybridisation buffer alone, as well as predigestion with RNAse, and confirmed the specificity of the staining. Preparations were observed with an Olympus BX60 fluorescence microscope equipped with Fuji FinePix S2 Pro and S3 Pro digital cameras (Fujifilm, Milan, Italy).

\section{ELISA}

Assays used are summarised in Table 2. Multiwell plates (Nunc, Milan, Italy) were coated with the corresponding synthetic peptide $(5-50 \mathrm{nmol} / 1$, in carbonate-bicarbonate buffer, $\mathrm{pH} 9 \cdot 6$, either for $4 \mathrm{~h}$ at $37^{\circ} \mathrm{C}$ or for $16 \mathrm{~h}$ at $0-4{ }^{\circ} \mathrm{C}$ ), hence were treated with normal serum from the secondary antibody donor species ( $90 \mathrm{ml} / 1$ in PBS, PBS-donkey). Primary incubations were carried out in duplicate, including relevant standards $(0 \cdot 005-500 \mathrm{nmol} / \mathrm{l})$, or serially diluted samples $(100 \mu \mathrm{l} /$ well incubation volume, in PBS-donkey for $4 \mathrm{~h}$ at room temperature under constant agitation). After the incubation $(1 \mathrm{~h})$ with the relevant, biotinylated secondary antibody (Jackson) and streptavidin-peroxidase conjugate (Biospa, Milan, Italy), wells were filled with tetramethylbenzidine substrate $(100 \mu \mathrm{l} /$ well; Kem-En-Tec Diagnostics, Taastrup, Denmark). Upon development, the reaction was stopped with $\mathrm{HCl}(1 \mathrm{~mol} / \mathrm{l}, 100 \mu \mathrm{l} /$ well $)$, and optical density was measured at $450 \mathrm{~nm}$ using a multilabel plate reader (Chameleon; Hidex, Turku, Finland). Synthetic peptides were used for assay characterisation.

Table 2 ELISA characterisation

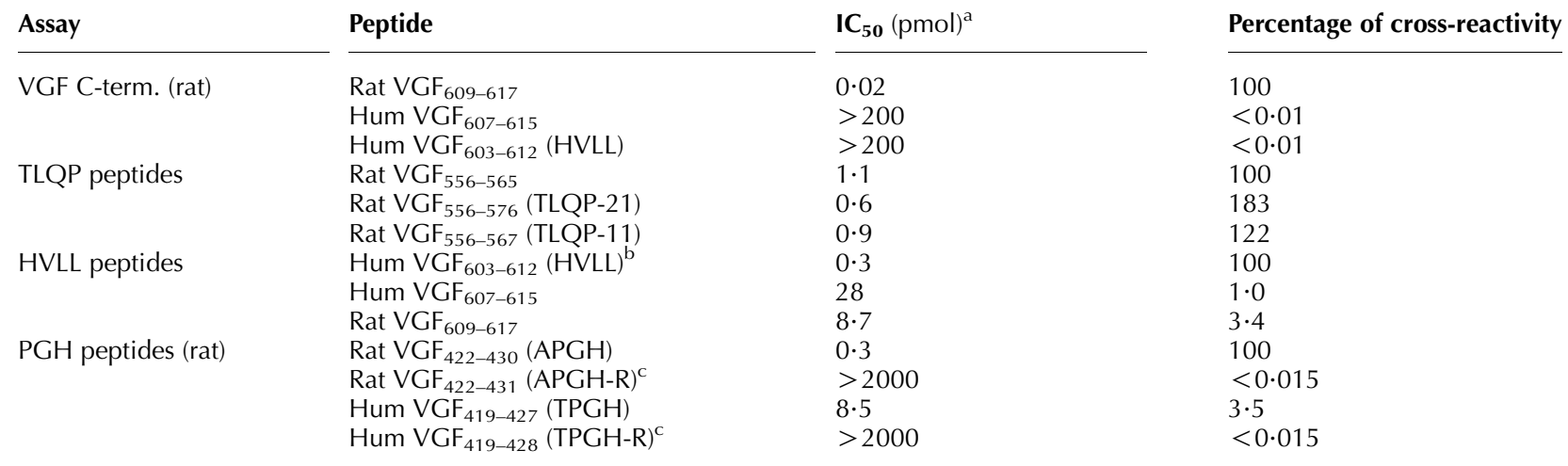

\footnotetext{
apmol per assay well, $100 \mu$ incubation volume.

bIdentical to rat $\mathrm{VGF}_{605-614}$.

${ }^{\mathrm{C}}$ For PGH peptide assays, cross-reaction with C-terminally extended forms, or the VGF precursor itself was addressed using peptides with an additional Arg residue at their C-terminus.
} 


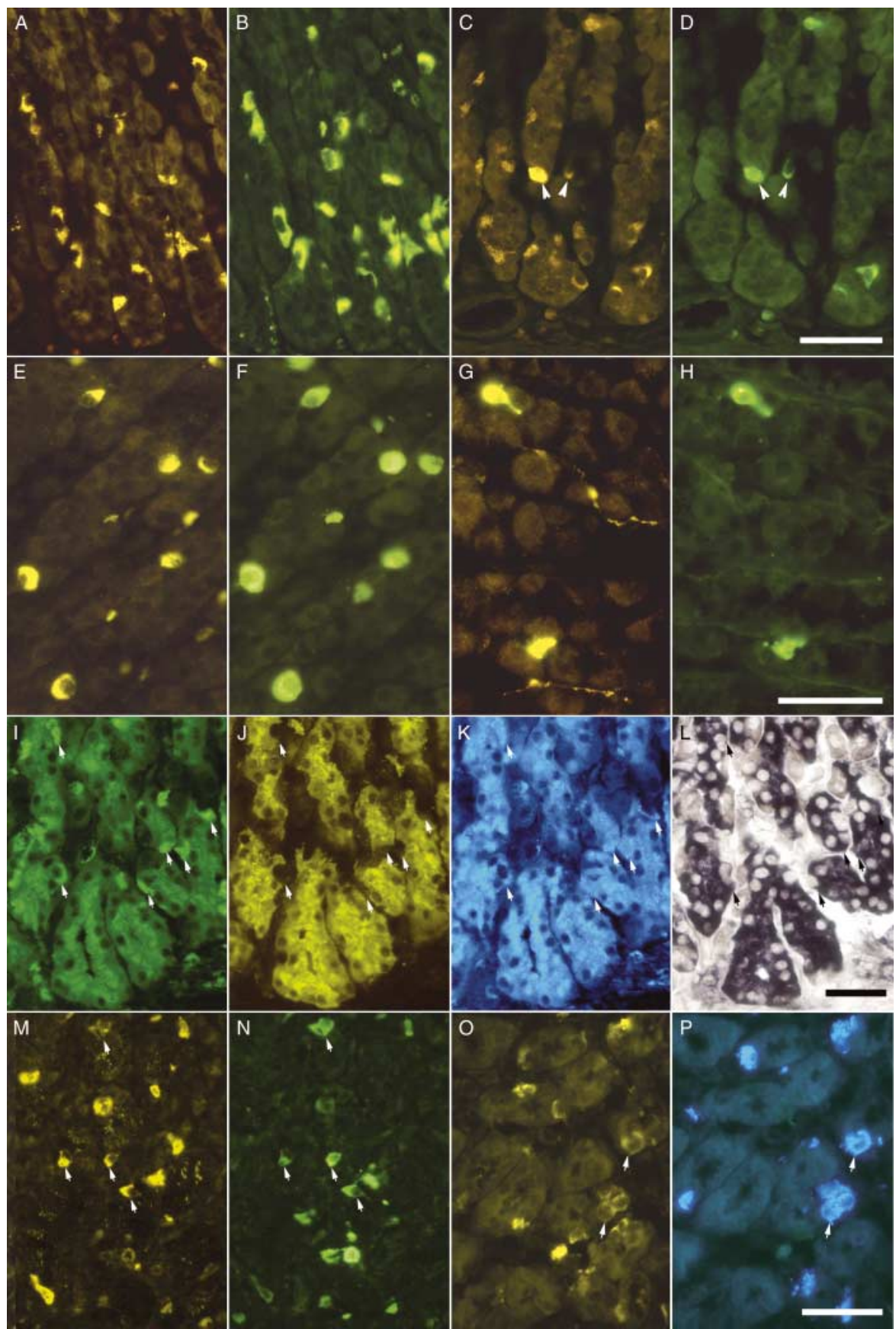

Figure 2 Differential distribution of VGF peptides in gastric endocrine cells. TLQP peptides were abundant and brightly labelled in VMAT-2-immunoreactive ECL cells (A: TLQP; B: VMAT-2), and in somatostatin cells (arrowheads in C: TLQP; D: somatostatin), irrespective of the animal's fed/fasted condition. Somatostatin cells, with the addition of a few mucosal nerve axons, were also labelled by the VGF $443-588$ antibody (G: $\mathrm{VGF}_{443-588} ; \mathrm{H}$ : somatostatin). PGH peptides were selectively shown in closed-type endocrine cells, recognised as ghrelincontaining cells in double immunofluorescence (E: PGH; F: ghrelin). At a distinctly lower intensity, TLQP immunoreactivity was revealed in a subpopulation of EC and G cells (M and O: TLQP; N: serotonin; P: gastrin), and in chief cells (about half of the animals, I: TLQP; J: pepsinogen), irrespective of the animal's feeding state. Diffuse low-intensity labelling for HVLL peptides was found in chief cells, in association with a prominent expression of VGF mRNA (I: TLQP; J: pepsinogen; K: HVLL peptides, all in the same section; L: VGF mRNA, in an immediately adjacent serial section). Single-cell profiles (arrows in panels I-K) can be seen to be negative for pepsinogen (K), while being labelled for the TLQP in the same section (I). In the adjacent serial section (L), corresponding cell profiles are seen to contain VGF mRNA. These represent ECL and/or somatostatin cells, few in number compared to chief cells. (A-L) Rat stomach, oxyntic region; (M-P) swine stomach, pyloric mucosa; scale bars: $50 \mu \mathrm{m}$. Full colour version of this figure available via http://dx.doi.org/10.1677/JOE-10-0189. 


\section{Chromatography}

Gastric extracts $(\sim 2 \mathrm{ml}, n=4+4)$ from rats of the fed and fasted groups respectively were individually loaded onto a Sephadex G-50S column (Sigma, $2 \mathrm{~cm}^{2} \times 1 \mathrm{~m}$ ), equilibrated with $50 \mathrm{mM}$ ammonium bicarbonate and eluted with the same buffer. A MW marker kit (MWGF70; Sigma) was used for column calibration. Fractions $(3 \mathrm{ml})$ were reduced in volume using a Vacufuge Concentrator (Eppendorf, Milan, Italy) and were assayed. Recovery after the chromatography ranged between 80 and $120 \%$ for all the peptides tested.

The relevant gel chromatography fractions (rat stomach, $n=3$; rat hypothalamus, $n=2$ ) were dried and redissolved in $200 \mu \mathrm{l}$ distilled water. HPLC was carried out using a Waters 1525 system, equipped with a $0 \cdot 46 \times 15 \mathrm{~cm}$ ODS ultra sphere C18 column (Beckman Coulter, Brea, CA, USA), and a variable wavelength u.v. detector. The mobile phase was made with two solvents: A and B. Solvent A was $0.5 \mathrm{~g} / 1$ trifluoroacetic acid (TFA) in water and solvent $B$ was $0.5 \mathrm{~g} / 1$ TFA in acetonitrile/water $(80 / 20, \mathrm{vol} / \mathrm{vol})$. A linear gradient was used, from 5 to $30 \%$ solvent B in $40 \mathrm{~min}$, then to $50 \%$ solvent $\mathrm{B}$ during the next $15 \mathrm{~min}$, at a $1 \mathrm{ml} / \mathrm{min}$ flow rate, at room temperature. Rat synthetic TLQP peptides (TLQP-11, TLQP-21, TLQP-30 and TLQP-62, all containing the TLQP sequence at their N-terminal end; Primm, Milan, Italy) were used as standards, and their elution times were measured by absorbance at $210 \mathrm{~nm}$. Twenty-five HPLC fractions $(2 \mathrm{ml})$ were collected, dried with a Vacufuge Concentrator, redissolved in PBS and tested in ELISA.

\section{Results}

Immunohistochemistry and in situ hybridisation

Most of the VGF antibodies used labelled endocrine cells in the rat gastric mucosa (Fig. 2), and their overall differential localisation is summarised in Table 3. As mentioned (see section Materials and Methods), absorption controls resulted in virtually complete prevention of immunostaining in each case (Fig. 3A and B). TLQP peptides were abundant and intensely labelled in cells of varied morphology, numerous in the oxyntic region (Fig. 2A and C). These were identified as VMAT-2-labelled, ghrelin-negative ECL cells (Fig. 2A and B), with the addition of somatostatin cells (Fig. 2C and D). Most ECL cells showed bright immunostaining for TLQP peptides $(94 \cdot 5 \pm 1 \cdot 4 \%$, mean \pm s.E.M., $n=4$ ), while almost all somatostatin cells were intensely labelled with both TLQP and $\mathrm{VGF}_{443-588}$ antibodies (96.9 $\pm 1 \cdot 1$ and $99 \cdot 6 \pm 0 \cdot 4 \%$ respectively; Fig. $2 \mathrm{C}, \mathrm{D}, \mathrm{G}$ and $\mathrm{H})$. Immunoreactivity for the novel PGH peptide/s was revealed in cells showing the typical morphology of closedtype endocrine cells, and mostly abundant in the oxyntic mucosa (Fig. 2E). These proved to be ghrelin-containing cells (Fig. 2E and F), with a virtually complete co-localisation profile (>98\%). Though few, antral ghrelin cells also contained PGH immunoreactivity.

A far weaker labelling pattern, clearly distinct from the one described for ECL, somatostatin and ghrelin cells, was revealed with several VGF peptide antibodies in additional rat gastric mucosal cells. The HVLL peptide antiserum (Fig. $2 \mathrm{~K}$ ) yielded a consistent, low-intensity immunostaining in chief cells (Fig. 2J), while TLQP antibodies weakly labelled a fraction of gastrin and $5-\mathrm{HT}$ cells $(5.9 \pm 1 \cdot 2$ and $15 \cdot 7 \pm 3 \cdot 8 \%$ of gastrin and $5-\mathrm{HT}$ cells, mean \pm s.E.M. respectively) as well as chief cells in about half of the animals (irrespective of their fed or fasted state; Fig. 2I-J). VGF C-terminus immunoreactivity was confined to neuronal structures, including myenteric perikarya and axons in all layers of the wall, with no labelling of endocrine or other mucosal cells, as reported previously (Severini et al. 2009). Nerve structures were also revealed by the $\mathrm{VGF}_{443-588}$ antiserum (Fig. 2G), with the addition of a small number of weakly labelled axons depicted by the HVLL antibodies, while no nerve labelling was obtained in the stomach with any further VGF antibody.

Table 3 Gastric mucosal elements showing VGF peptide immunoreactivity. Summary of the localisation of VGF peptides studied in gastric mucosal cells, including various endocrine cell populations and chief cells, as well as in the gastric innervation

\section{Gastric cell type}

\begin{tabular}{|c|c|c|c|c|c|c|}
\hline ECL & D & X/A like & $\mathrm{EC}$ & G & Chief cells & Neuronal structures \\
\hline++++ & ++++ & - & $t^{a}$ & $t^{a}$ & $\pm^{b}$ & - \\
\hline- & & ++++ & - & - & - & - \\
\hline- & - & - & - & - & $+^{c}$ & + \\
\hline- & ++++ & - & - & - & - & +++ \\
\hline- & - & - & - & - & - & ++++ \\
\hline
\end{tabular}

Intense immunoreactivity, ++++ ; low immunoreactivity, + ; no immunoreactivity, - .

${ }^{\mathrm{a}}$ In $15 \cdot 7 \pm 3 \cdot 8 \%$ of EC cells and $5 \cdot 9 \pm 1 \cdot 2 \%$ of $\mathrm{G}$ cells, fed rats, mean \pm S.E.M., $n=4$.

${ }^{\mathrm{b}}$ About half of the animals, irrespective of fed/fasted state.

${ }^{\mathrm{c}}$ All animals, immunostained neuronal structures included axons in the mucosal lamina propria, submucosa and muscle layers, and a fraction of perikarya in myenteric ganglia. 

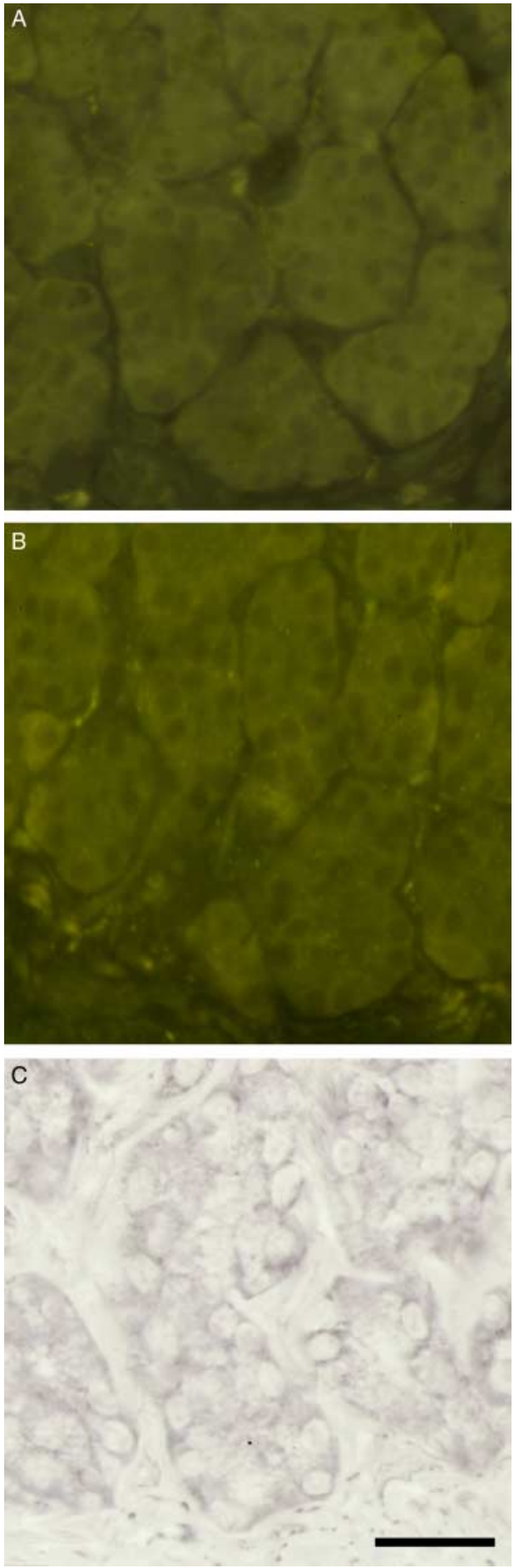

Figure 3 Negative control sections for immunohistochemistry and in situ hybridisation. Sections from rat oxyntic mucosa showed no labelling with TLQP and HVLL antisera ( $A$ and $B$ respectively), when pre-absorbed with their respective peptides. Similarly, in situ hybridisation resulted in no labelling, when the sense probe was used (C). Scale bar: $50 \mu \mathrm{m}$. Full colour version of this figure available via http://dx.doi.org/10.1677/JOE-10-0189.
While VGF mRNA was traced to each of the above VGF peptide-containing cell types in serial sections, the most prominent VGF mRNA-containing population was composed of pepsinogen-, as well as HVLL-immunoreactive chief cells in fundic glands (Fig. 1J-L). Corresponding sense probe controls were negative (Fig. 3C). Multiple myenteric perikarya expressed VGF mRNA in the various regions of the stomach (Fig. 4C), while submucous perikarya were seen only occasionally.

To gain some insight into another mammalian species, a few parallel experiments were carried out by immunocytochemistry on pig gastric mucosa, encompassing the cardiac, oxyntic and antral regions. The overall VGF peptide localisation in swine gastric endocrine cells proved comparable with the one seen in rat, namely in ECL, ghrelin and somatostatin cells, as well as in a subpopulation of antral serotonin (Fig. 2M and N) and gastrin cells (Fig. $2 \mathrm{O}$ and $\mathrm{P}$ ). Neither HVLL nor TLQP labelling was seen in swine chief cells. Since porcine VGF has not been sequenced, the antisera against the human and rat VGF C-terminus peptides were both tested. The former proved most effective in labelling a few bright mucosal axons, but not endocrine cells (the muscolaris externa was not included in the swine specimen studied).

Since TLQP peptides were originally identified and sequenced from the rat brain (Trani et al. 2002, Bartolomucci et al. 2006), we briefly tested their distribution in the rat brain, compared with VGF C-terminus peptides (Fig. 4A and B). While the latter were widely distributed, TLQP peptides were mostly found in the hypothalamic region, in densely labelled terminal fields in the external layer of the median eminence (Fig. 4B), with the addition of delicately labelled axons in the medial hypothalamus (especially in the arcuate, peri- and para-ventricular regions). While their analysis is beyond the scope of the present investigation, scattered VGF C-terminus-immunoreactive perikarya were seen in the medial hypothalamus and in other brain regions. VGF C-terminus and TLQP peptides appeared to co-distribute and co-localise in portions of the external median eminence (Fig. 4A and B).

\section{Immunochemistry and molecular heterogeneity}

In the stomach of ad libitum fed rats, TLQP peptides were most abundant $(162 \pm 11 \mathrm{pmol} / \mathrm{g}$, mean \pm s.E.M., $n=12)$. Lower concentrations were found for PGH $(24 \pm 4 \cdot 0 \mathrm{pmol} / \mathrm{g})$, HVLL $(12 \pm 1 \cdot 2 \mathrm{pmol} / \mathrm{g})$ and VGF C-terminus peptides $(7 \cdot 4 \pm 1 \cdot 0 \mathrm{pmol} / \mathrm{g})$.

Upon Sephadex chromatography (Fig. 5), several forms of TLQP peptides were shown in stomach extracts (Fig. 5A), including: (a) a major wide peak in the $\sim 2 \cdot 5-6 \mathrm{kDa}$ region and (b) a lower peak at $\sim 8 \mathrm{kDa} \mathrm{MW}$, broadly corresponding to a similar one seen for VGF C-terminus and HVLL peptides (Fig. 5B and D), with the addition of low amounts of immunoreactivity in the low MW and void volume fractions. Upon reverse-phase HPLC (Fig. 6, upper panel), fractions 

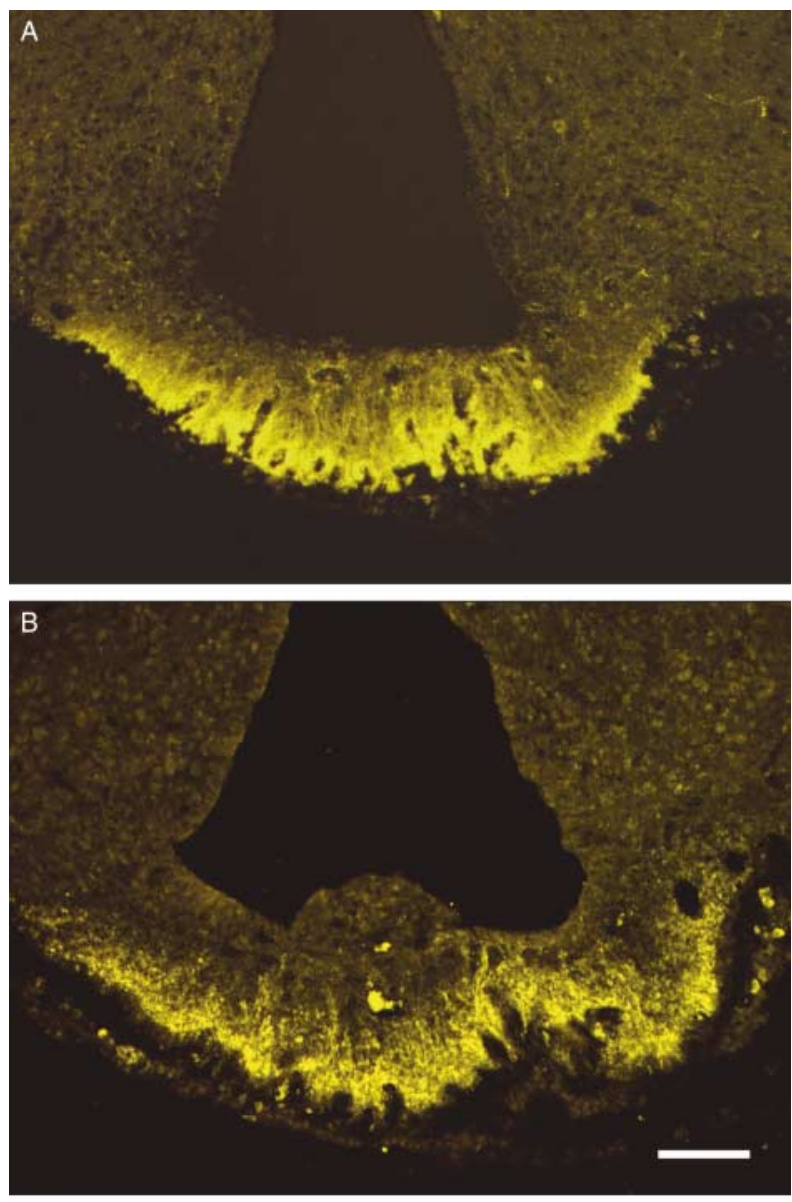

C

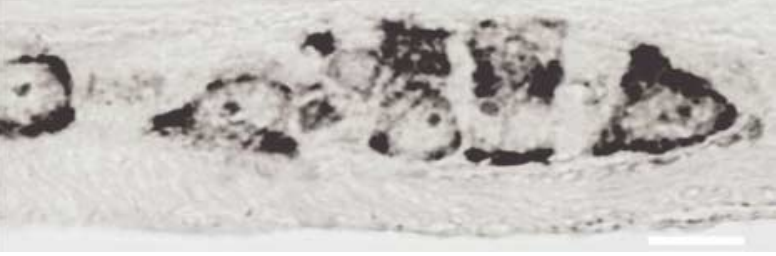

Figure 4 VGF peptides in rat hypothalamus, and VGF mRNA in myenteric neurons. VGF C-terminus peptides were most abundant in the median eminence (A), with the addition of thin axons in various hypothalamic regions, while TLQP peptides were mostly seen in the external layer of the median eminence (B). In the rat stomach, in situ hybridisation revealed a proportion of myenteric perikarya labelled for VGF mRNA (C). Scale bar in (A and B) $50 \mu \mathrm{m}$ (C) $20 \mu \mathrm{m}$. Full colour version of this figure available via http://dx. doi.org/10.1677/JOE-10-0189.

related to the (a) peak showed TLQP immunoreactivity at elution positions coinciding with synthetic TLQP-21 and TLQP-30 standards, with the addition of a larger molecular form eluting shortly after the latter. When fractions corresponding to the (b) peak were similarly loaded, a small amount of reactivity was found at a position eluting earlier than the TLQP-62 standard. The latter fractions showed HVLL peptide, but no detectable VGF C-terminus immunoreactivity in ELISA $(\sim 0.5$ and $<0.1 \mathrm{pmol} / \mathrm{HPLC}$ fraction respectively). When hypothalamic extracts were similarly analysed by Sephadex chromatography and HPLC, TLQP peptides co-eluting with the TLQP-21 and TLQP-62 standards were revealed (Fig. 6), with the addition of an unknown form apparently co-eluting with the one seen in the gastric extracts. In ELISA, hypothalamic HPLC fractions co-eluting with the TLQP-62 standard did show VGF C-terminus immunoreactivity $(\sim 1.13 \mathrm{pmol} /$ fraction $)$, in agreement with the presence of authentic TLQP-62. PGH peptides (Fig. 5C) mostly eluted as low MW forms in Sephadex chromatography, $\sim 0 \cdot 8-1.5 \mathrm{kDa}$ in range, with the addition of a broad peak close to the void volume.

For the study of the VGF peptide response to feeding, as mentioned, the entire stomach from each rat was extracted for VGF peptide assays. Clear-cut, selective differences were found for TLQP peptides, which showed more than 50\% decrease in fasted animals (Fig. 7; $162 \pm 11 \mathrm{vs} 74 \pm 5 \cdot 3 \mathrm{pmol} / \mathrm{g}$, fed versus fasted rats, mean \pm s.e.m., $P<0 \cdot 00001)$. Conversely, none of the other VGF peptide studies showed any significant change (Fig. 7). Immunohistochemistry of fed and fasted animal samples did not reveal distinct changes for either TLQP or other VGF peptides, neither in their immunostaining intensity nor in the abundance of labelled cells. Hence, co-localisation of VGF peptides versus the relevant cell marker/s, or hormone, was addressed quantitatively, and revealed no change in the relevant co-localisation profiles between the fed and fasted groups (Table 4). Comparable molecular profiles were revealed in the two groups in gel chromatography (data not shown).

Data were expressed as mean \pm s.E.M. throughout. Statistical analyses were carried out by one-way ANOVA followed by $t$-test as appropriate (StatistiXL software, www.statistixl.com).

\section{Discussion}

On the basis of this study, VGF-derived peptide/s appear to be well represented in the stomach of rat and swine. The comparable distribution we observed in the two species, as shown previously for the pancreas and adrenal glands (Cocco et al. 2007, D'Amato et al. 2008), fits well with the largely conserved sequence of the VGF precursor from rat to human, including virtually all its internal cleavage sites (Salton et al. 2000). The far higher reactivity found in pig for human (compared with rat) VGF C-terminus antibodies suggests that swine VGF, which is yet to be sequenced, may be similar to the human form in its C-terminal region.

Major cleaved VGF products showed a distinct differential distribution in the stomach, TLQP peptides being expressed at high level in ECL and D cells, and PGH peptides in ghrelin 

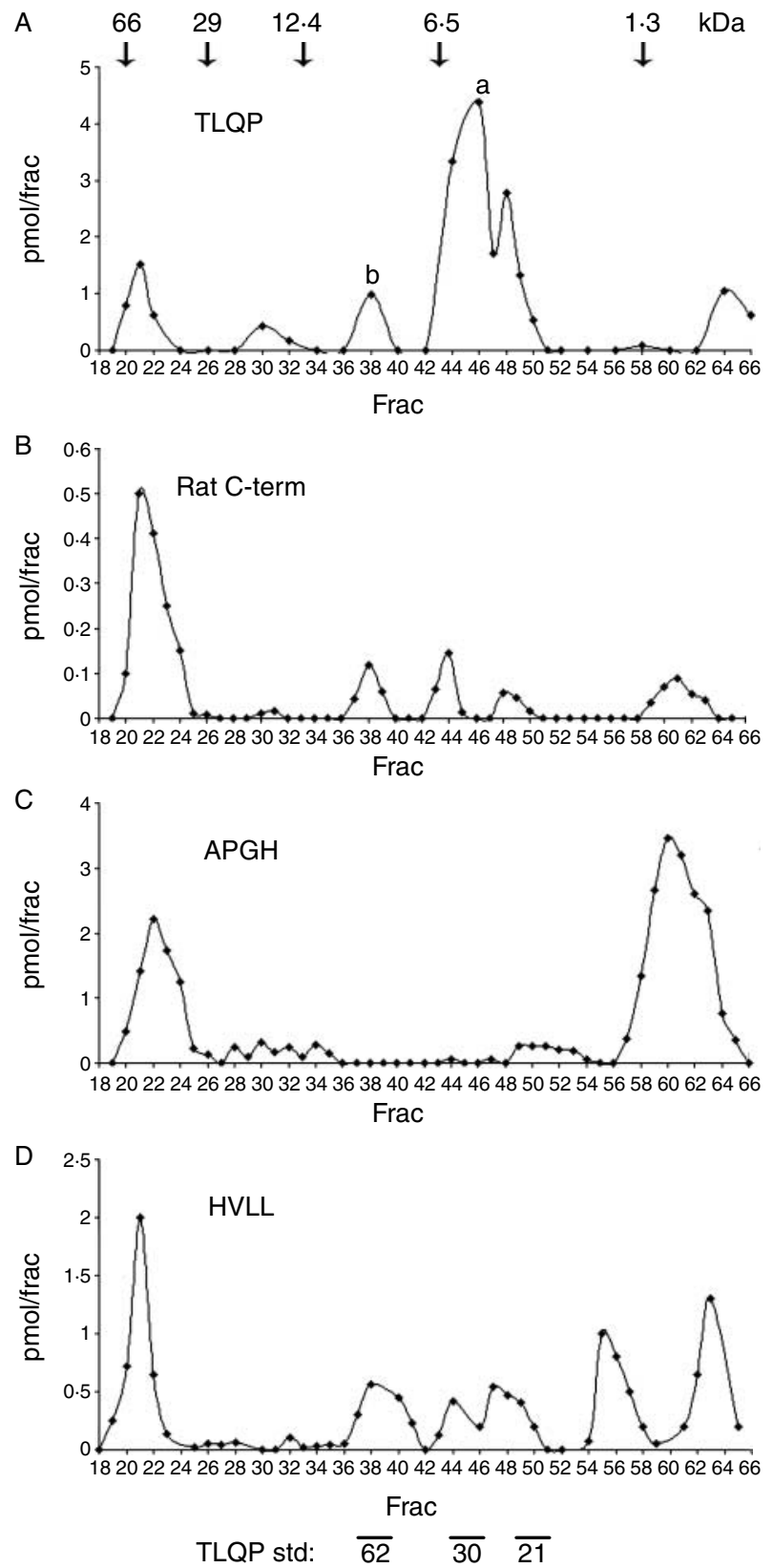

Figure 5 VGF peptides in Sephadex chromatography of gastric extracts. Several forms of TLQP peptides were shown (A), including a major wide peak in the $\sim 2 \cdot 5-6 \mathrm{kDa}$ region (a), and a lower peak at $\sim 8 \mathrm{kDa} \mathrm{MW}(\mathrm{b})$, broadly corresponding to a similar one seen for VGF C-terminus (B) and HVLL peptides (D), with the addition of low amounts of immunoreactivity in the low MW and void volume fractions. PGH peptides (C) mostly eluted as low MW forms in Sephadex chromatography, in an $\sim 0 \cdot 8-1.5 \mathrm{kDa}$ range, with the addition of a broad peak close to the void volume. Representative chromatography profiles from the fed rat group. Molecular weight markers are shown in (A), while 'TLQP std' 62, 30 and 21 indicate the elution positions of the respective peptide standards (D). cells. Conversely, VGF C-terminus-containing peptides were confined to neuronal structures, including intrinsic gut neurons and probably axons of extrinsic origin. Co-localisation of the above VGF peptides with VGF mRNA, and the additional presence of $\mathrm{VGF}_{443-588} \mathrm{immu-}$ noreactivity in certain location/s (e.g. D cells) strongly argue for authentic VGF peptides being revealed. In addition, VGF mRNA is one of the mRNAs expressed in highly purified ECL cell preparations, while absent in the parietal cell fraction (Lambrecht et al. 2006).

ECL cells appeared to selectively express TLQP peptides, including authentic TLQP-21, as well as the following additional forms: a) a TLQP-30 peptide, related to cleavage at the rat $\mathrm{VGF}_{586-587}$ Arg-Arg sequence; b) an additional form that could be tentatively cleaved at a further Arg-Arg sequence (rat $\mathrm{VGF}_{597-598}$ ); and c) a longer peptide extending towards the VGF C-terminus, but distinct from TLQP-62. A further point is that TLQP peptides (only) were selectively modulated by changes in the nutritional status, with a clearcut reduction in tissue TLQP peptide/s content on fasting. ECL cells appeared to be the major cell population involved, with the possible addition of somatostatin cells, which also contained TLQP and some other peptides related to the $\mathrm{VGF}_{443-588}$ region. Previous studies using purified preparations of ECL cells showed a significant reduction in VGF mRNA on fasting ( $\sim 49 \%$ decrease, Lambrecht et al. 2007), thus indicating that the changes observed may be at least partly regulated at the transcriptional level. In our investigation, VGF mRNA was expressed in the oxyntic mucosa by numerous chief cells, largely obscuring any change one might observe in the comparatively few ECL and somatostatin cells. In addition, indirect immunofluorescence and the in situ hybridisation method used (Moorman et al. 2001) were set up aiming for the highest possible sensitivity, rather than to a proportional representation of the quantitative peptide or mRNA content in each cell. Hence, changes in both the techniques of the order mentioned above may result in minor differences in the overall detection signal (fluorochromelabelled secondary antibody, or alkaline phosphatase reaction product respectively), when the change diffusely affects the cell population/s involved. Furthermore, the consistent pattern of TLQP peptide co-localisation in fed and fasted animals, as confirmed by quantitative analysis, further supports a general involvement of the ECL (and possibly somatostatin) cell populations.

In the fasting rat, ECL cells showed a decrease in both their L-histidine substrate uptake transporter SN2 and their VMAT-2 responsible for histamine uptake into the secretory vesicles (Dimaline et al. 1993b, Dimaline \& Struthers 1996, Lambrecht et al. 2007). The reduction in histamine biosynthesis required under fasting conditions would thus be achieved by reducing substrate availability, as well as the histamine secretory pool, rather than inhibiting the biosynthetic enzyme histidine decarboxylase (Lambrecht et al. 2007). The localisation of TLQP peptides in both ECL and $\mathrm{D}$ cells is also intriguing, in view of their inhibitory 


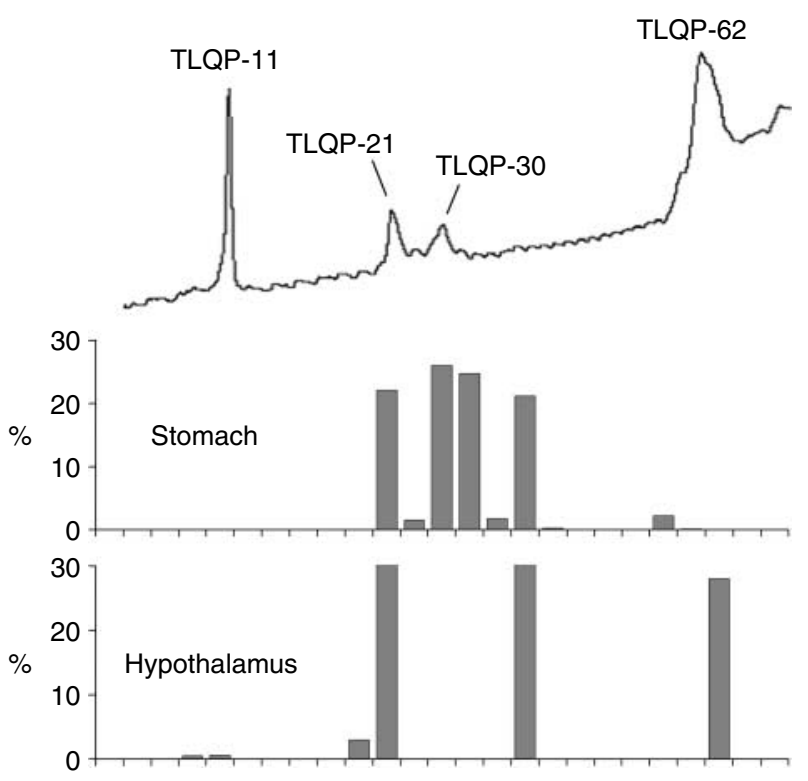

Figure 6 TLQP peptides in HPLC chromatography of gastric and hypothalamic extracts. In the extracts of rat stomach (middle panel), distinct peaks co-eluting with synthetic TLQP-21 and TLQP-30 were revealed, together with a possibly larger molecular form eluting shortly after the latter. A small amount of reactivity was found at an elution position earlier than the TLQP-62 standard. Conversely, in hypothalamic extracts, TLQP peptides co-eluting with the TLQP-21 and TLQP-62 standards were revealed (bottom panel), together with an unknown form apparently co-eluting with the one seen in gastric extracts. Representative HPLC chromatography from the fed rat group. Bars represent percentages of total TLQP immunoreactivity measured in all fractions from each chromatography.

connection in the fundic stomach, and the resulting effects upon ECL cell histamine and gastric acid secretion (Dimaline et al. 1993a,b, Lambrecht et al. 2006). On the whole, TLQP peptides could have a role in the regulatory machinery of the ECL cells or, upon release from ECL and/or somatostatin cells, could act locally in a paracrine manner or via neuroendocrine pathways such as those involving the vagus nerve (Dockray 2009). So far, peripheral administration of TLQP-21 proved uneffective (Jethwa et al. 2007, Severini et al. 2009). In the brain, TLQP-62 and TLQP-21 were suggested to have an agonist-antagonist action upon hippocampal synaptic potentiation (Bozdagi et al. 2007), while the bioactivity of the additional forms we found remains to be studied.

Though unchanged in fasting/feeding conditions, the localisation of novel VGF-derived products, namely $\mathrm{PGH}$ peptides in ghrelin cells, warrants the precise identification of the molecular species involved. Of these, the high MW form we observed close to the void volume might correspond to a product cleaved at the rat $\mathrm{VGF}_{431-433}$ putative cleavage site (Arg-Arg-Lys, Salton et al. 2000) and encompassing an extensive domain towards the VGF N-terminus. In the adrenal gland, $\mathrm{PGH}$ peptides were also present in a comparable profile of molecular forms; however, PGH immunoreactivity was broadly localised in the whole medulla, while TLQP peptides were confined to adrenalin cells (D'Amato et al. 2008). The same or similar peptides were also found in human, in ECL tumour cells (Rindi et al. 2007).

The localisation of VGF mRNA and the related peptide/s immunoreactivity in further gastric endocrine and mucosal cells is worth noting. The TLQP immunoreactivity found in a fraction of gastrin and serotonin cells, in both rat and swine, may indicate a low expression of the relevant peptide/s. Extended molecular forms, of low reactivity with the antibodies we used, could also be involved, as shown for certain endocrine cell types in sheep pituitary (Brancia et al. 2005). Most human G- and EC-cell tumours, be it of gastric, intestinal or pancreatic origin, appeared to display both C-terminal and PGH peptide immunoreactivity to an extent comparable to ECL tumours, while TLQP peptides were not investigated (Rindi et al. 2007). As for the chief cells, the intense mRNA signal, consistent immunostaining for HVLL peptides, and the occasional labelling with TLQP antibodies all converge to indicate local synthesis of the VGF precursor, at least in rat. Whether further cleavage products or the HVLL peptide/s themselves are part of the functional machinery of such cell type remains to be determined. Interestingly, gastric chief cells have been shown to produce and release peptide hormones including gastric leptin (Bado et al. 1998) and apelin (Susaki et al. 2005). On the other hand, the localisation of VGF peptides in the gastric chief cells suggests that they might be secreted into the gastric lumen from where they would travel and act onto different locations, as seen for leptin and apelin released into the gastric lumen and stimulating

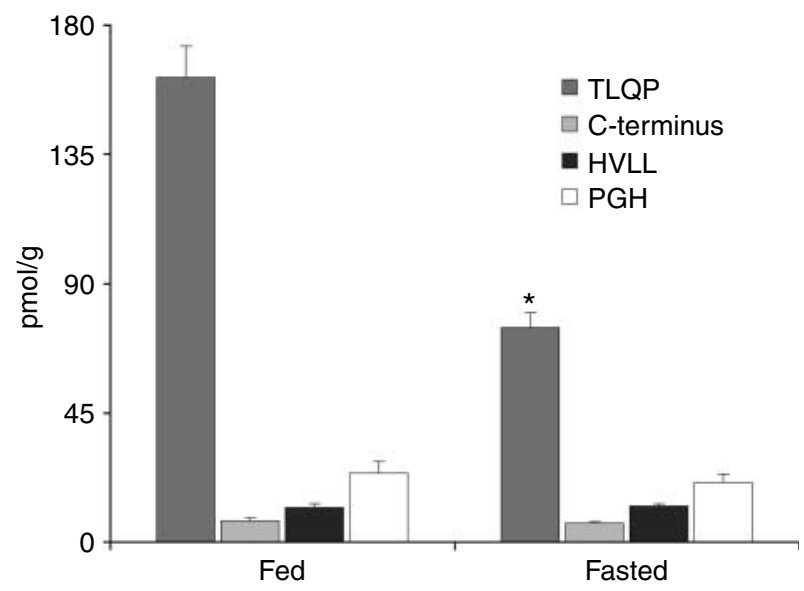

Figure 7 VGF peptide immunoreactivity in the whole stomach, the fed versus fasted rat groups. TLQP peptides were most abundant, followed by PGH peptides, hence the others studied. A clear-cut, selective decrease in TLQP peptides (only) was revealed in fasted rats compared with fed ones, while all other VGF peptides studied were unchanged. The whole stomach was extracted for the assay from each animal. Data are expressed as mean \pm S.E.M., $n=12$ male rats/group. ${ }^{*} P<0 \cdot 00001$ 
Table 4 VGF peptides in gastric endocrine cells: co-localisation profiles in fed versus fasted rats. Upper panel: the majority of enterochromaffin-like cells (ECL), D and X/A-type endocrine cells showed the relevant VGF peptide immunoreactivity in both fed and fasted animals, with no significant change in co-localisation profiles. Lower panel: TLQP peptide/s-containing cells were largely identified as ECL cells, with the addition of a lower number of D cells, and a small fraction of further uncharacterised cells. No significant shift in the contribution of either cell type to the overall TLQP-containing population was revealed between fed and fasted rats. Data are expressed as mean \pm s.E.M., $n=4$ rats/group. Endocrine cell types were characterised on the basis of their relevant markers, or hormone (see section Materials and Methods)

Percentage of immunostained cells

\begin{tabular}{|c|c|c|c|c|}
\hline & \multirow[b]{2}{*}{ VGF peptide immunostained } & \multirow[b]{2}{*}{ Fed group (\%) } & \multirow[b]{2}{*}{ Fasted group (\%) } & \multirow[b]{2}{*}{$\boldsymbol{P}$} \\
\hline & & & & \\
\hline \multicolumn{5}{|l|}{ Endocrine cell type } \\
\hline $\mathrm{ECL}$ & TLQP & $97 \cdot 9 \pm 0 \cdot 9$ & $94 \cdot 0 \pm 4 \cdot 8$ & $0 \cdot 4$ \\
\hline $\mathrm{D}$ & TLQP & $98 \cdot 0 \pm 0 \cdot 8$ & $98 \cdot 6 \pm 1 \cdot 4$ & $0 \cdot 3$ \\
\hline $\mathrm{D}$ & VGF $_{443-588}$ & $98 \cdot 0 \pm 1 \cdot 9$ & $93 \cdot 4 \pm 3 \cdot 9$ & $0 \cdot 3$ \\
\hline \multirow{3}{*}{ X/A like } & PGH & $98 \cdot 7 \pm 1 \cdot 6$ & $97 \cdot 8 \pm 2 \cdot 3$ & $0 \cdot 4$ \\
\hline & & \multicolumn{2}{|c|}{ Percentage of TLQP immunostained cells } & \\
\hline & Endocrine cell type & Fed group & Fasted group & $\boldsymbol{P}$ \\
\hline \multirow{4}{*}{$\begin{array}{l}\text { VGF peptide immunostained } \\
\text { TLQP }\end{array}$} & & & & \\
\hline & $\mathrm{ECL}$ & $90 \cdot 3 \pm 1 \cdot 2$ & $92 \cdot 9 \pm 1 \cdot 9$ & $0 \cdot 6$ \\
\hline & & $6 \cdot 3 \pm 0 \cdot 9$ & $6 \cdot 5 \pm 1 \cdot 7$ & $0 \cdot 6$ \\
\hline & Not characterised & $3 \cdot 4 \pm 1 \cdot 4$ & $0 \cdot 6 \pm 0 \cdot 3$ & $0 \cdot 1$ \\
\hline
\end{tabular}

CCK secretion in the proximal small intestine (Sobhani et al. 2002, Susaki et al. 2005).

While the investigation of nerve pathways containing VGF peptides is beyond the scope of this paper, the selective localisation of VGF C-terminus peptides in myenteric neurons, and in mucosal nerves probably including at least some of extrinsic origin, should not to be overlooked. In fact, VGF mRNA was rapidly induced in both sensory and efferent vagal neurons upon cysteamine ulceration of the duodenum (Kanemasa et al. 1995a,b), suggesting an involvement of yet-to-be-determined VGF peptides in the gastric response to injury or other stimuli, and possibly in mucosal defence mechanisms. The only VGF peptide studied so far, TLQP-21, induced gastric longitudinal muscle contraction in vivo, while inhibiting gastric emptying when given i.c.v. (Severini et al. 2009).

The heterogeneity of VGF peptides implies complex posttranslational processing mechanisms. The action of prohormone convertases PC1/3 and PC2 on the VGF precursor has been studied, and showed that $\mathrm{PC} 1 / 3$ is responsible for cleavage at the N-terminus of TLQP and other peptides (Trani et al. 2002), in keeping with the accumulation of the C-terminal VGF-derived peptide $\mathrm{V}$ in mice lacking PC1/3 (Pan et al. 2005). Conversely, the enzyme/s affecting C-terminal cleavage of TLQP-21, as well as others involved in the production of multiple VGF peptides revealed in the human cerebro-spinal fluid (Selle et al. 2005) remain to be clarified. A parallel is often drawn between VGF and the chromograninsecretogranin family of proteins, because of their selective localisation in secretory granules, as well as their role as precursors of multiple bioactive peptides (Helle 2004). Chromogranins, too, are differentially processed in gastric endocrine cells (Watkinson et al. 1991, Watkinson \& Dockray 1992,
Portela-Gomes \& Stridsberg 2002), although to a profile different from the one we observed for VGF peptides. In fact, G cells showed immunoreactivity to virtually all region-specific antibodies to chromogranin A (Portela-Gomes \& Stridsberg 2002), as opposed to the limited reactivity of VGF peptides we could demonstrate in such cell type.

In conclusion, diverse VGF peptides appear to be selectively expressed in different gastric endocrine and other mucosal cells. Of these, TLQP peptides rapidly respond to feeding conditions. Their further investigation is warranted, with respect to their possible involvement in mechanisms regulating the response to feeding and starvation, as well as the neuro-endocrine integratory pathways connecting the gut and the brain.

\section{Declaration of interest}

The authors declare that there is no conflict of interest that could be perceived as prejudicing the impartiality of the research reported.

\section{Funding}

This study was partly supported by research grants from MIUR FIRB (RBNE013XSJ_002 and RBNE01JKLF_002 to G L F) and Ministry of Health, Italy. C B and B N were supported by an RAS grant (Regione Autonoma Sardegna, PO FSE 2007-1013, L.R. 7/2007 for promotion of Scientific Research and Technological Innovation in Sardinia).

\section{Author contribution statement}

F D, B N and C B carried out the ELISA assays; F S and A A performed the HPLC; C B and C C performed the immunohistochemistry; C B and R P performed the in situ hybridisation; G L F raised the VGF antibodies and supervised the study; and C B, C C and G L F wrote the paper. 


\section{Acknowledgements}

M Collu, B Tuveri and M Tuveri, as well as M C Mostallino at the Institute of Neuroscience, National Research Council (CNR), Cagliari are acknowledged for rat housing; G Boi, F Incollu and the COALBE Company for swine tissues; P Nicolussi for animal housing for antibody production.

\section{References}

Bado A, Levasseur S, Attoub S, Kermorgant S, Laigneau JP, Bortoluzzi MN, Moizo L, Lehy T, Guerre-Millo M, Le Marchand-Brustel Y et al. 1998 The stomach is a source of leptin. Nature 394 790-793. (doi:10.1038/29547)

Bartolomucci A, La Corte G, Possenti R, Locatelli V, Rigamonti AE, Torsello A, Bresciani E, Bulgarelli I, Rizzi R, Pavone F et al. 2006 TLQP-21, a novel VGF-derived peptide, increases energy expenditure and prevents the early phase of diet-induced obesity. PNAS 103 14584-14589. (doi:10.1073/pnas. 0606102103)

Bartolomucci A, Possenti R, Levi A, Pavone F \& Moles A 2007 The role of the $v g$ gene and VGF-derived peptides in nutrition and metabolism. Genes \& Nutrition 2 169-180. (doi:10.1007/s12263-007-0047-0)

Bozdagi O, Huntley GW \& Salton S 2007 Role of VGF peptide in hippocampal synaptic function. Program No. 760.9. 2007 Neuroscience Meeting Planner. San Diego, CA: Society for Neuroscience, Online.

Bozdagi O, Rich E, Tronel S, Sadahiro M, Patterson K, Shapiro ML, Alberini CM, Huntley GW \& Salton SR 2008 The neurotrophininducible gene Vgf regulates hippocampal function and behavior through a brain-derived neurotrophic factor-dependent mechanism. Journal of Neuroscience 28 9857-9869. (doi:10.1523/JNEUROSCI.3145-08.2008)

Brancia C, Nicolussi P, Cappai P, La Corte G, Possenti R \& Ferri GL 2005 Differential expression and seasonal modulation of VGF peptides in sheep pituitary. Journal of Endocrinology 186 97-107. (doi:10.1677/joe.1.05992)

Cocco C, Melis GV \& Ferri GL 2003 Embedding media for cryomicrotomy: an applicative reappraisal. Applied Immunohistochemistry and Molecular Morphology 11 274-280. (doi:10.1097/00129039-200309000-00012)

Cocco C, Brancia C, Pirisi I, D’Amato F, Noli B, Possenti R \& Ferri GL 2007 VGF metabolic-related gene: distribution of its derived peptides in mammalian pancreatic islets. Journal of Histochemistry and Cytochemistry $\mathbf{5 5}$ 619-628. (doi:10.1369/jhc.6A7040.2007)

D'Amato F, Noli B, Brancia C, Cocco C, Flore G, Collu M, Nicolussi P \& Ferri GL 2008 Differential distribution of VGF-derived peptides in the adrenal medulla and evidence for their selective modulation. Journal of Endocrinology 197 359-369. (doi:10.1677/JOE-07-0346)

Dimaline R \& Struthers J 1996 Expression and regulation of a vesicular monoamine transporter in rat stomach: a putative histamine transporter. Journal of Physiology 490 249-256.

Dimaline R, Evans D, Forster ER, Sandvik AK \& Dockray GJ 1993a Control of gastric corpus chromogranin A messenger RNA abundance in the rat. American Journal of Physiology 264 583-588.

Dimaline R, Sandvik AK, Evans D, Forster ER \& Dockray GJ 1993b Food stimulation of histidine decarboxylase messenger RNA abundance in rat gastric fundus. Journal of Physiology 465 449-458.

Dockray GJ 2009 The versatility of the vagus. Physiology \& Behavior 97 531-536. (doi:10.1016/j.physbeh.2009.01.009)

Ferri G-L, Levi A \& Possenti R 1992 A novel neuroendocrine gene product: selective VGF8a gene expression and immunolocalization of the VGF protein in endocrine and neuronal population. Brain Research. Molecular Brain Research 13 139-143. (doi:10.1016/0169-328X(92)90053-E)

Ferri GL, Gaudio RM, Cossu M, Rinaldi AM, Polak JM, Berger P \& Possenti R 1995 The "VGF" protein in rat adenohypophysis: sex differences and changes during the estrous cycle and after gonadectomy. Endocrinology $\mathbf{1 3 6}$ 2244-2251. (doi:10.1210/en.136.5.2244)

Hahm S, Mizuno TM, Wu TI, Wisor JP, Priest CA, Kozoc CA, Boozer CN, Peng B, Mcevoy RC \& Good P 1999 Targeted deletion of the vof gene indicates that the encoded secretory peptide precursor plays a novel role in the regulation of energy balance. Neuron 23 537-548. (doi:10.1016/S08966273(00)80806-5)
Hahm S, Fekete C, Mizuno TM, Windsor J, Yan H, Boozer CN, Lee C, Elmquist JK, Lechan RM, Mobbs CV et al. 2002 VGF is required for obesity induced by diet, gold thioglucose treatment, and Agouti and is differentially regulated in pro-opiomelanocortin- and neuropeptide Y-containing arcuate neurons in response to fasting. Journal of Neuroscience 22 6929-6938.

Helle KB 2004 The granin family of uniquely acidic proteins of the diffuse neuroendocrine system: comparative and functional aspects. Biological Reviews of the Cambridge Philosophical Society 79 769-794. (doi:10.1017/ S146479310400644X)

Jethwa PH \& Ebling JPE 2008 Role of VGF-derived peptides in the control of food intake, body weight and reproduction. Neuroendocrinology 88 80-87. (doi:10.1159/000127319)

Jethwa PH, Warner A, Nilaweera KN, Brameld JM, Keyte JW, Carter WG, Bolton N, Bruggraber M, Morgan PJ, Barrett P et al. 2007 VGF-derived peptide, TLQP-21, regulates food intake and body weight in Siberian hamsters. Endocrinology 148 4044-4055. (doi:10.1210/en.2007-0038)

Kanemasa K, Okamura H, Kodama T \& Ibata Y 1995a Induction of VGF mRNA in neurons of the rat nucleus tractus solitarius and the dorsal motor nucleus of vagus in duodenal ulceration by cysteamine. Brain Research. Molecular Brain Research 32 55-62. (doi:10.1016/0169-328X(95)00059-2)

Kanemasa K, Okamura H, Kodama T, Kashima K \& Ibata Y 1995 b Time course of the induction of VGF mRNA in the dorsal vagal complex in rats with cysteamine-induced peptic ulcers. Brain Research. Molecular Brain Research 34 309-314. (doi:10.1016/0169-328X(95)00183-S)

Lambrecht NWG, Yakubov I, Zer C \& Sachs G 2006 Transcriptomes of purified gastric ECL and parietal cells: identification of a novel pathway regulating acid secretion. Physiological Genomics 25 153-165. (doi:10.1152/ physiolgenomics.00271.2005)

Lambrecht NWG, Yakubov I \& Sachs G 2007 Fasting-induced changes in ECL cell gene expression. Physiological Genomics 31 183-192. (doi:10.1152/ physiolgenomics.00252.2006)

Levi A, Ferri GL, Watson E, Possenti R \& Salton SR 2004 Processing, distribution, and function of VGF, a neuronal and endocrine peptide precursor. Cellular and Molecular Neurobiology 24 517-533. (doi:10.1023/ B:CEMN.0000023627.79947.22)

Moorman AFM, Houweling AC, de Boer PAJ \& Christoffels VM 2001 Sensitive non-radioactive detection of mRNA in tissue section: novel application of the whole-mount in situ hybridization protocol. Journal of Histochemistry and Cytochemistry 49 1-8.

Pan H, Nanno D, Che FY, Zhu X, Salton SR, Steiner DF, Fricker LD \& Devi LA 2005 Neuropeptide processing profile in mice lacking prohormone convertase-1. Biochemistry 44 4939-4948. (doi:10.1021/bi047852m)

Portela-Gomes GM \& Stridsberg M 2002 Chromogranin A in the human gastrointestinal tract: an immunocytochemical study with region-specific antibodies. Journal of Histochemistry and Cytochemistry 50 1487-1492.

Possenti R, Eldridge JD, Paterson BM, Grasso A \& Levi A 1989 A protein induced by NGF in PC 12 cells is stored in secretory vesicles and release through the regulated pathway. EMBO Journal 8 2217-2223.

Possenti R, Rinaldi AM, Ferri GL, Borboni P, Trani E \& Levi A 1999 Expression, processing, and secretion of the neuroendocrine VGF peptides by INS-1 cells. Endocrinology 140 3727-3735. (doi:10.1210/en.140.8.3727)

Rindi G, Necchi V, Savio A, Torsello A, Zoli M, Locatelli V, Raimondo F, Cocchi D \& Solcia E 2002 Characterisation of gastric ghrelin cells in man and other mammals: studies in adult and fetal tissues. Histochemistry and Cell Biology 117 511-519. (doi:10.1007/s00418-002-0415-1)

Rindi G, Licini L, Necchi V, Bottarelli L, Campanini N, Azzoni C, Favret M, Giordano G, D'Amato F, Brancia C et al. 2007 Peptide products of the neurotrophin-inducible gene $v g$ are produced in human neuroendocrine cells from early development and increase in hyperplasia and neoplasia. Journal of Clinical Endocrinology and Metabolism 92 2811-2815. (doi:10.1210/ jc.2007-0035)

Salton SRJ, Ferri GL, Hahm S, Snyder SE, Wilson AJ, Possenti R \& Levi A 2000 VGF: a novel role for this neuronal and neuroendocrine polypeptide in the regulation of energy balance. Frontiers in Neuroendocrinology 21 199-219. (doi:10.1006/frne.2000.0199)

Selle H, Lamerz J, Buerger K, Dessauer A, Hager K, Hampel H, Karl J, Kellmann M, Lannfelt L, Louhija J et al. 2005 Identification of novel 
biomarker candidates by differential peptidomics analysis of cerebrospinal fluid in Alzheimer's disease. Combinatorial Chemistry \& High Throughput Screening 8 801-806. (doi:10.2174/138620705774962391)

Severini C, La Corte G, Improta G, Broccardo M, Agostini M, Petrella C, Sibilia V, Pagani F, Guidobono F, Bulgarelli I et al. 2009 In vitro and in vivo pharmacological role of TLQP-21, a VGF-derived peptide, in the regulation of rat gastric motor functions. British Journal of Pharmacology 157 984-993. (doi:10.1111/j.1476-5381.2009.00192.x)

Sobhani I, Buyse M, Goiot H, Weber N, Laigneau JP, Henin D, Souls JC \& Bado A 2002 Vagal stimulation rapidly increase leptin secretion in human stomach. Gastroenterology 122 259-263. (doi:10.1053/gast.2002.31385)

Solcia E, Rindi G, Buffa R, Fiocca R \& Capella C 2000 Gastric endocrine cells: types function and growth. Regulatory Peptides 93 31-35. (doi:10.1016/S0167-0115(00)00175-0)

Stengel A, Goebel M, Yakubov I, Wang L, Witcher D, Coskun T, Taché Y, Sachs G \& Lambrecht NW 2009 Identification and characterization of nesfatin-1 immunoreactivity in endocrine cell types of the rat gastric oxyntic mucosa. Endocrinology 150 232-238. (doi:10.1210/en.2008-0747)

Susaki E, Wang G, Cao G, Wang H-Q, Englander EW \& Greeley GH 2005 Apelin cells in the rat stomach. Regulatory Peptides 129 37-41. (doi:10. 1016/j.regpep.2005.01.013)

Trani E, Ciotti T, Rinaldi AM, Canu N, Ferri GL, Levi A \& Possenti R 1995 Tissue-specific processing of the neuroendocrine protein VGF. Journal of Neurochemistry 65 2441-2449. (doi:10.1046/j.1471-4159.1995.65062441.x)

Trani E, Giorgi A, Canu N, Amadoro G, Rinaldi AM, Halban PA, Ferri G-L, Possenti R, Schinina ME \& Levi A 2002 Isolation and characterization of
VGF peptides in rat brain Role of $\mathrm{PC} 1 / 3$ and $\mathrm{PC} 2$ in the maturation of VGF precursor. Journal of Neurochemistry 81 565-574. (doi:10.1046/j.14714159.2002.00842.x)

Watkinson A \& Dockray GJ 1992 Functional control of chromogranin A and B concentrations in the body of the stomach. Regulatory Peptides 40 51-61. (doi:10.1016/0167-0115(92)90083-7)

Watkinson A, Jönsson AC, Davison M, Young J, Lee CM, Moore S \& Dockray GJ 1991 Heterogeneity of chromogranon A-derived peptides in bovine gut, pancreas and adrenal medulla. Biochemical Journal 276 471-479.

Watson E, Fargali S, Okamoto H, Sadahiro M, Gordon RE, Chakraborty T, Sleeman MW \& Salton SR 2009 Analysis of knockout mice suggests a role for VGF in the control of fat storage and energy expenditure. $B M C$ Physiology 28 9-19. (doi:10.1186/1472-6793-9-19)

Yamaguchi H, Sasaki K, Satomi Y, Shimbara T, Kageyama H, Mondal MS, Toshinai K, Date Y, González LJ, Shioda S et al. 2007 Peptidomic identification and biological validation of neuroendocrine regulatory peptide-1 and -2. Journal of Biological Chemistry 282 26354-26360. (doi:10.1074/jbc.M701665200)

Received in final form 22 September 2010 Accepted 27 September 2010 Made available online as an Accepted Preprint 27 September 2010 